\title{
Study on Preparation of Immobilized Alkaline Protease and Its Performance
}

\author{
Yiming Li, Fei Xue, Dengxin Li \\ College of Environmental Science and Engineering, Donghua University, Shanghai, China \\ Email address: \\ lymilx@163.com (Yiming Li), xuefeiwin@outlook.com (Fei Xue), lidengxin@dhu.edu.com (Dengxin Li)
}

\section{To cite this article:}

Yiming Li, Fei Xue, Dengxin Li. Study on Preparation of Immobilized Alkaline Protease and Its Performance. Modern Chemistry. Vol. 5, No. 3, 2017, pp. 35-42. doi: 10.11648/j.mc.20170503.11

Received: April 27, 2017; Accepted: May 8, 2017; Published: May 10, 2017

\begin{abstract}
The nano- $\mathrm{Fe}_{3} \mathrm{O}_{4}$ particles were prepared by hydrothermal method. Cellulose-based magnetic $\mathrm{Fe}_{3} \mathrm{O}_{4}$ was prepared by adding cellulose solution dissolved in sodium hydroxide / thiourea / urea system. The basic protease was used as the catalyst and glutaraldehyde was used as the crosslinking agent, The production of magnetic recyclable immobilized enzyme can greatly reduce the cost of hydrolysis of sludge. The aldehyde groups in the glutaraldehyde and the amino groups in the protein can be stably crosslinked by coupling. The immobilization effect of nanometer $\mathrm{Fe}_{3} \mathrm{O}_{4}$ was reflected by investigating the activity of immobilized enzyme and immobilization rate of enzyme under different conditions.
\end{abstract}

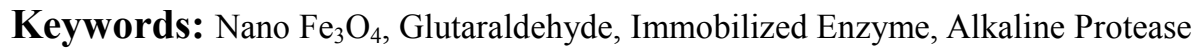

\section{Introduction}

With the development of urbanization and the continuous improvement of people's living standards, the demand for water has also been an upward trend. The workload of sewage treatment plant is growing, resulting in more and more excess sludge. The treatment of sludge is a difficult problem at home and abroad. It will cause secondary pollution without proper treatment. The currently widely used physical and chemical methods have the disadvantage of high cost and low efficiency. The residual sludge has a high moisture content, which sometimes reaches $99 \%$. So, sludge dewatering is an important part of the treatment of sludge. How to quickly and effectively reduce the sludge moisture content has been a key issue at home and abroad research. [1]

EPS is the polymer organic compounds secreted by microbial organism in the sludge under certain conditions. The main component is the protein and polysaccharide. EPS is the main cause of loose floc sludge structure. Water will be tightly absorbed by the protein and polysaccharide in EPS, leading to the decline of dehydration performance. Therefore, reducing the EPS content in the sludge, destroying its floc structure, releasing absorbed water, will play a positive role in improving the sludge dewatering performance. [2]

The enzymatic hydrolysis of residual sludge has the advantages of high catalytic efficiency, low pollution, low energy consumption and simple operation. But there are some defects: free enzyme can not be recovered and the cost is high. In order to solve the defects in the use of enzymes, academics began to try a variety of reusable enzymes and increase the applicability of the enzyme technology. In all these researches, enzyme immobilization has the best prospects for application and industrialization. The immobilized enzyme has the following advantages compared with the water-soluble enzyme: (1) The use efficiency is high, the cost is low, and the specificity is strong; (2) The substrate is easy to be separated from the enzyme, the product quality is improved, and the yield of the product is increased; (3) The enzyme can be used repeatedly; (4) In most cases, immobilization can improve the stability of the enzyme to extend the use of the enzyme and its shelf life; (5) Immobilized enzyme has a certain mechanical strength. It can react with the substrate solution by stirring or packing, which is convenient for the continuous and automated operation of enzyme catalyzation reaction. Therefore, the current academic research on immobilized enzyme technology is getting more and more popular. A variety of carrier production technology and enzyme immobilization technology is arising. [3]

In comparison with free proteases in solution, immobilized proteases are reportedly stable, highly resistant to 
environmental changes and reusable. The four principal methods of immobilization are as follows: (a) adsorption, (b) covalent binding, (c) entrapment, and (d) membrane confinement. Among these, multipoint covalent attachment is the most effective in terms of thermal stabilization. Protease has been successfully immobilized on many different types of carriers, including a controlled amine terminal magnetic particle, chitosan beads, extrusion soybean fiber, and a magnetic polymer microsphere. Among all these carriers, magnetic nanoparticles can overcome the inconvenience in recycling and handling which can be recovered easily from reaction solutions by simple magnetic capture. [4]

\section{Material and Methods}

\subsection{Equipment and Reagents}

Main equipment: Analytical balance (Ohaus Corporation), Thermo high-speed centrifuge (Thermo Fisher), ultrasonic cleaner, freeze dryer, constant temperature water bath oscillator.

Main reagents: liquid paraffin, Span80, sodium hydroxide, thiourea, urea, microcrystalline cellulose, acetone, ethanol, alkaline protease, casein. Folin-phenol reagent, $0.4 \mathrm{~mol} / \mathrm{L}$ sodium carbonate solution, $0.4 \mathrm{~mol} / \mathrm{L}$ trichloro acetic acid (TCA, $\mathrm{CCl}_{3} \mathrm{COOH}$ ) solution, Coomassie brilliant blue solution. [5]

\subsection{Solution Preparation}

Cellulose solution: Sodium hydroxide / thiourea / urea / deionized water was prepared as a solution at a rate of $8 / 6.5$ $/ 8 / 77.5$, cooled to $-10^{\circ} \mathrm{C}$, and then slowly heated at $2000 \mathrm{r} /$ min with $3 \mathrm{~g}$ of micro Crystalline cellulose, prepared into $3 \%$ cellulose solution. [6]

Buffer solution:

Solution A: $0.2 \mathrm{~mol} / \mathrm{L} \mathrm{Na}_{2} \mathrm{HPO}_{4} \cdot 2 \mathrm{H}_{2} \mathrm{O}$ solution;

Solution B: $0.2 \mathrm{~mol} / \mathrm{L} \mathrm{NaH}_{2} \mathrm{PO}_{4} \cdot 2 \mathrm{H}_{2} \mathrm{O}$ solution;

Buffer solution is prepared as follows:.

Table 1. Table of buffer solution preparation method.

\begin{tabular}{lll}
\hline $\mathbf{p H}$ & $\mathbf{A} / \mathbf{m l}$ & $\mathbf{B} / \mathbf{m l}$ \\
\hline 5.8 & 8.0 & 92.0 \\
6.0 & 12.3 & 87.7 \\
6.5 & 31.5 & 68.5 \\
7.0 & 61.0 & 39.0 \\
7.5 & 84.0 & 16.0 \\
8.0 & 94.7 & 5.3 \\
\hline
\end{tabular}

\section{Experimental Methods}

\subsection{Preparation of Cellulose-Based $\mathrm{Nano} \mathrm{Fe}_{3} \mathrm{O}_{4}$ by Hydrothermal Method}

$100 \mathrm{~mL}$ of $0.3 \mathrm{~mol} / \mathrm{L} \mathrm{FeSO}_{4}$ solution and $0.15 \mathrm{~mol} / \mathrm{L} \mathrm{Fe}_{2}$
$\left(\mathrm{SO}_{4}\right)_{3}$ solution was poured into a $500 \mathrm{~mL}$ beaker at a molar ratio of 1: 1 and placed in a $65^{\circ} \mathrm{C}$ water bath. $\mathrm{NaOH}$ solution was used to adjust the $\mathrm{pH}$ of the solution to about 6.5 , and then added an excess of $25 \%$. Appropriate amount of surfactant sodium oleate and sodium dodecyl benzene sulfonate was added to the beaker with intensive stir. After thirty minutes of reaction, the product was poured into the reaction vessel. the reaction temperature was set at $160^{\circ} \mathrm{C}$ and the reaction time was $6 \mathrm{~h}$. The reaction was carried out by heating the reaction vessel. After the reaction was completed, the product was taken out, mechanically stirred for 30min, and ultrasonically dispersed for 30min. Then it was washed with distilled water and acetone. Immobilized enzyme was settled by strong magnet and supernatant was poured out. The whole procedure should be repeated for 4 to 5 times until the $\mathrm{pH}$ of supernatant reached 7 . The supernatant should be mechanically stirred and ultrasonic dispersed again for $30 \mathrm{~min}$. After that, the particles was collected by magnet and then be frozen-dried, and those particles was the nano $\mathrm{Fe}_{3} \mathrm{O}_{4}$. [7]

\subsection{Preparation of Immobilized Enzyme}

$300 \mathrm{ml}$ of liquid paraffin and $20 \mathrm{ml}$ of Span 80 were added to a three-necked flask and stirred at $20^{\circ} \mathrm{C}$ for $45 \mathrm{~min}$. $1 \mathrm{~g}$ of nano $\mathrm{Fe}_{3} \mathrm{O}_{4}$ was placed in $15 \mathrm{ml}$ of deionized water and ultrasonically dispersed for 15 minutes. Then it was added to $40 \mathrm{ml}$ of a cellulose solution for mechanical stirring. After completion of the emulsification, the suspension was added dropwise to the three-necked flask with a burette in about 1 hour. Emulsification was continued for 5 hours. After the end of emulsification, the $\mathrm{pH}$ of the system was adjusted to 7 by diluted hydrochloric acid. Then the suspension was settled until it was layered. After that, the supernatant was poured out. The particles left was washed by acetone, ethanol and deionized water repeatedly. Then it was frozen-dried and stored in refrigerator. [8]

$0.1 \mathrm{~g}$ of the prepared magnetic carrier was added to a certain amount of $25 \%$ glutaraldehyde solution. The suspension was water-bathed in oscillator at $25^{\circ} \mathrm{C}$ for some time, rinsed with buffer solution for 3 times. Then $1 \mathrm{ml}$ of enzyme solution was added to the suspension. The suspension was water-bathed in oscillator at $25^{\circ} \mathrm{C}$ for another one hour. At last, the immobilized enzyme was washed with buffer solution for 3 times and then kept in refrigerator.

\subsection{Determination of Enzyme Immobilization Effect}

a. Tyrosine Standard Curve Drawing

Sixteen test tubes were divided into 5 groups (one blank, each group has three parallel samples) and numbered. Standard tyrosine, deionized water, $0.4 \mathrm{~mol} / \mathrm{L}$ sodium carbonate and Folin-phenol reagent was added to test tubes according to the table, and water-bathed under $400^{\circ} \mathrm{C}$ for 20min. 721 spectrophotometer was used for colorimetric determination (wavelength $660 \mathrm{~nm}$ ). The concentration of $0 \mathrm{~g} /$ $\mathrm{mL}$ tyrosine solution was used as a blank control. 
Table 2. Table of tyrosine standard curve drawing.

\begin{tabular}{|c|c|c|c|c|c|c|c|}
\hline \multirow{2}{*}{ No } & & & Standard Tyrosine & Water & $\mathrm{Na}_{2} \mathrm{CO}_{3}$ & Folin-phenol & Tyrosine Content \\
\hline & & & $100 \mu \mathrm{g} / \mathrm{ml}$ & $\mathbf{m l}$ & $\mathbf{m l}$ & ml & $\mu \mathrm{g} / \mathrm{ml}$ \\
\hline Blank & & & 0 & 1.0 & 5 & 1 & 0 \\
\hline 1 & & & 0.2 & 0.8 & 5 & 1 & 20 \\
\hline 2 & & & 0.4 & 0.6 & 5 & 1 & 40 \\
\hline 3 & & & 0.6 & 0.4 & 5 & 1 & 60 \\
\hline 4 & & & 0.8 & 0.2 & 5 & 1 & 80 \\
\hline 5 & 1.0 & 0 & 5 & 1 & & 100 & \\
\hline
\end{tabular}

The curve drawn according to the data is shown in figure 1:

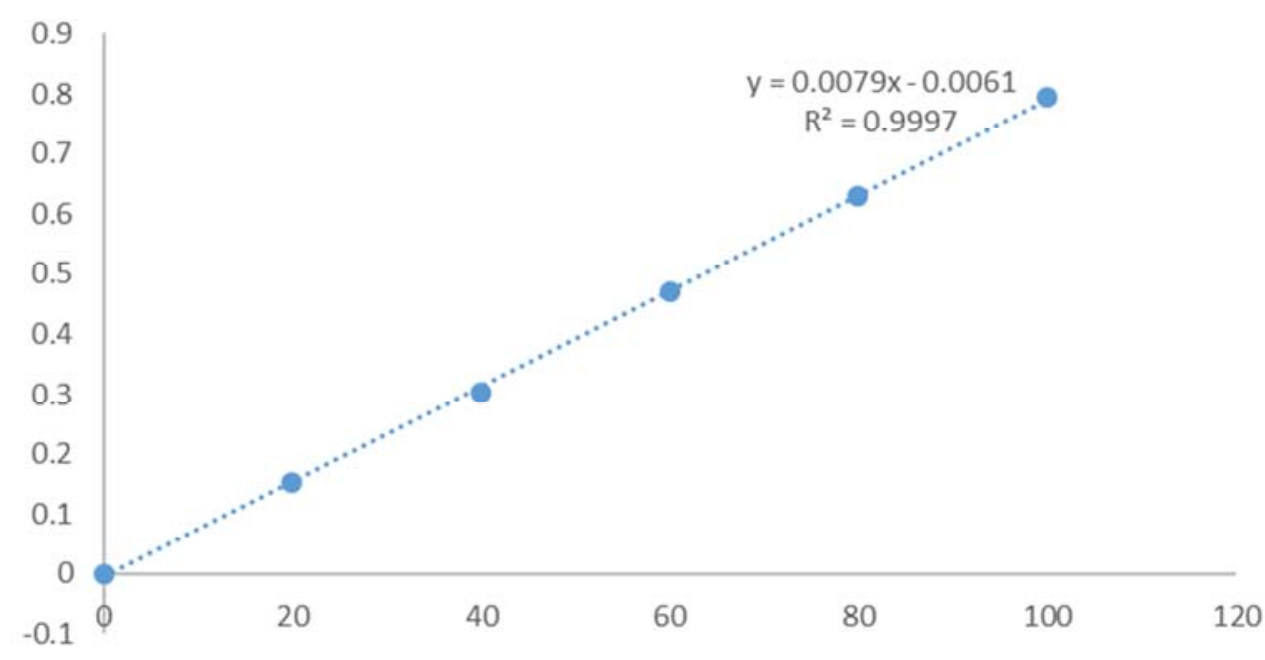

Figure 1. Tyrosine Standard Curve.

b. Enzyme Activity Determination

$0.1 \mathrm{~g}$ of fixed enzyme and $0.9 \mathrm{ml}$ phosphate buffer was added to a test tube. The test tube was preheated in $40^{\circ} \mathrm{C}$ water bath for 5 minutes. Then $1 \mathrm{~mL}$ of $2 \%$ casein substrate buffer was added to the suspension, shaken well. The test tube was placed in a water bath for $20 \mathrm{~min}$. Then it was settled for 15 minutes. The remaining casein and enzyme protein precipitate was filtered by filter paper. $1 \mathrm{~mL}$ of filtrate were transferred to each of another four test tubes. Then $5 \mathrm{~mL}$ of $0.4 \mathrm{~mol} / \mathrm{L}$ sodium carbonate solution and $1 \mathrm{~mL}$ of $1 \mathrm{~N}$ Folin-phenol reagent was added to the solution, shaken well. The test tube was water-bathed under a certain temperature for $20 \mathrm{~min}$ coloring. Then it was determined under $660 \mathrm{~nm}$ wave length. The tyrosine content was calculated by comparing the optical density values in the standard curve. [9]

\subsection{Determination of Enzyme Activity Recovery Rate}

Bovine serum albumin standard solution (BSA) was accurately moved into test tube according to table 3 . The total volume was adjusted to $1 \mathrm{~mL}$ by adding distilled water. And then $20 \mathrm{~mL}$ of Coomassie Brilliant Blue G-250 solution was added into the test tubes. The solution was shaken and measured at the wavelength of $595 \mathrm{~nm}$ absorbance. BSA standard solution concentration is used as the abscissa, absorbance as the ordinate. Standard curve is shown in figure 2. [10]

Table 3. Table of BSA standard curve drawing.

\begin{tabular}{|c|c|c|c|c|}
\hline \multirow{2}{*}{ No } & BSA standard solution & Water & G-250 & BSA Content \\
\hline & $100 \mu \mathrm{g} / \mathrm{ml}$ & ml & ml & $\mu \mathrm{g} / \mathrm{ml}$ \\
\hline Blank & 0 & 1.0 & 20 & 0 \\
\hline 1 & 0.2 & 0.8 & 20 & 20 \\
\hline 2 & 0.4 & 0.6 & 20 & 40 \\
\hline 3 & 0.6 & 0.4 & 20 & 60 \\
\hline 4 & 0.8 & 0.2 & 20 & 80 \\
\hline 5 & 1.0 & 0 & 20 & 100 \\
\hline
\end{tabular}




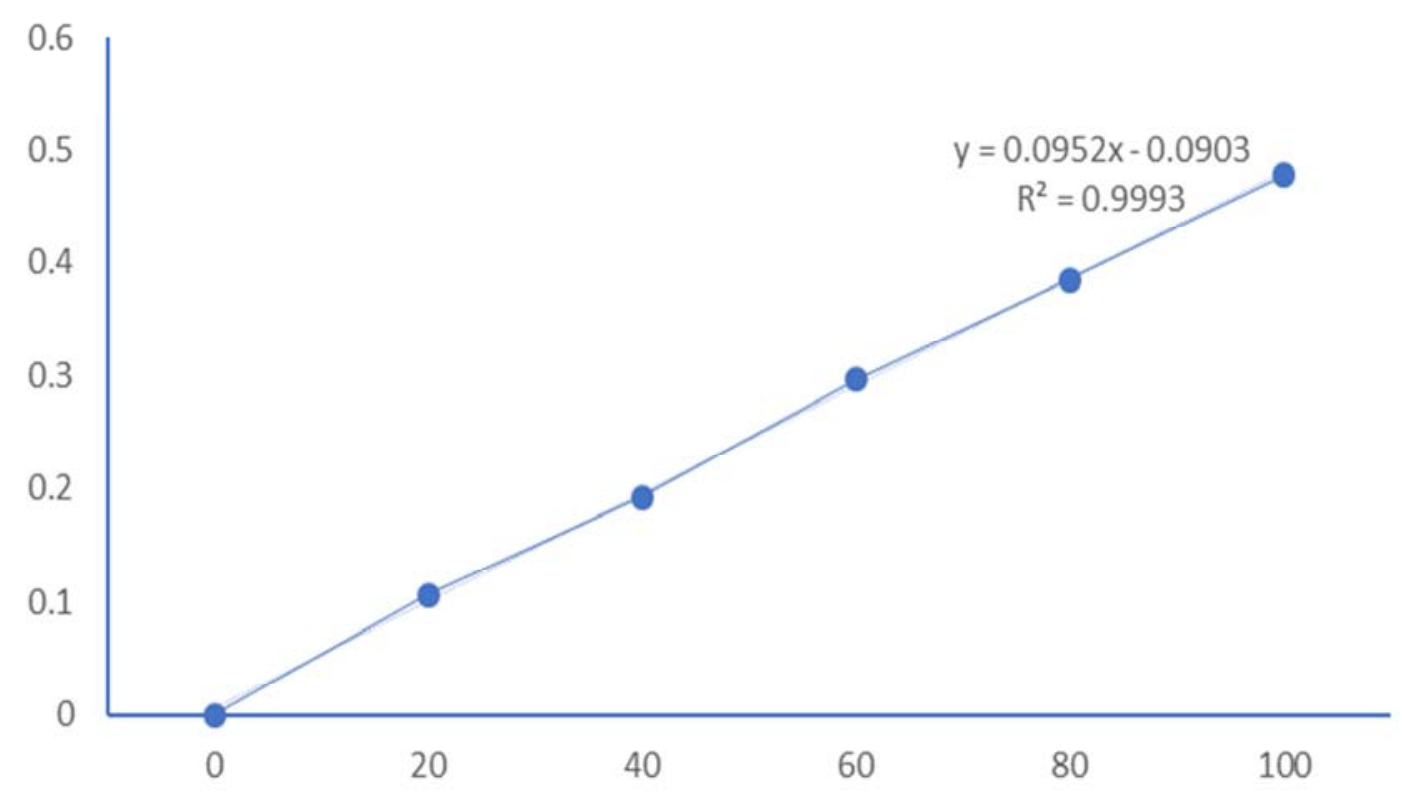

Figure 2. BSA Standard Curve.

\section{Result and Discussion}

Figure 3. shows the effect of different enzyme dosage on the recovery of immobilized enzyme activity. It can be seen from the figure that the recovery rate of immobilized enzyme activity grows with the increase of enzyme dosage. When the amount of enzyme is $500 \mu$, the recovery rate is the highest. After that, the activity recovery rate began to decline. This is because the amount of active groups is certain. When it reaches the cross-linked saturation, increase the amount of enzyme will no longer increase the enzyme retention rate.

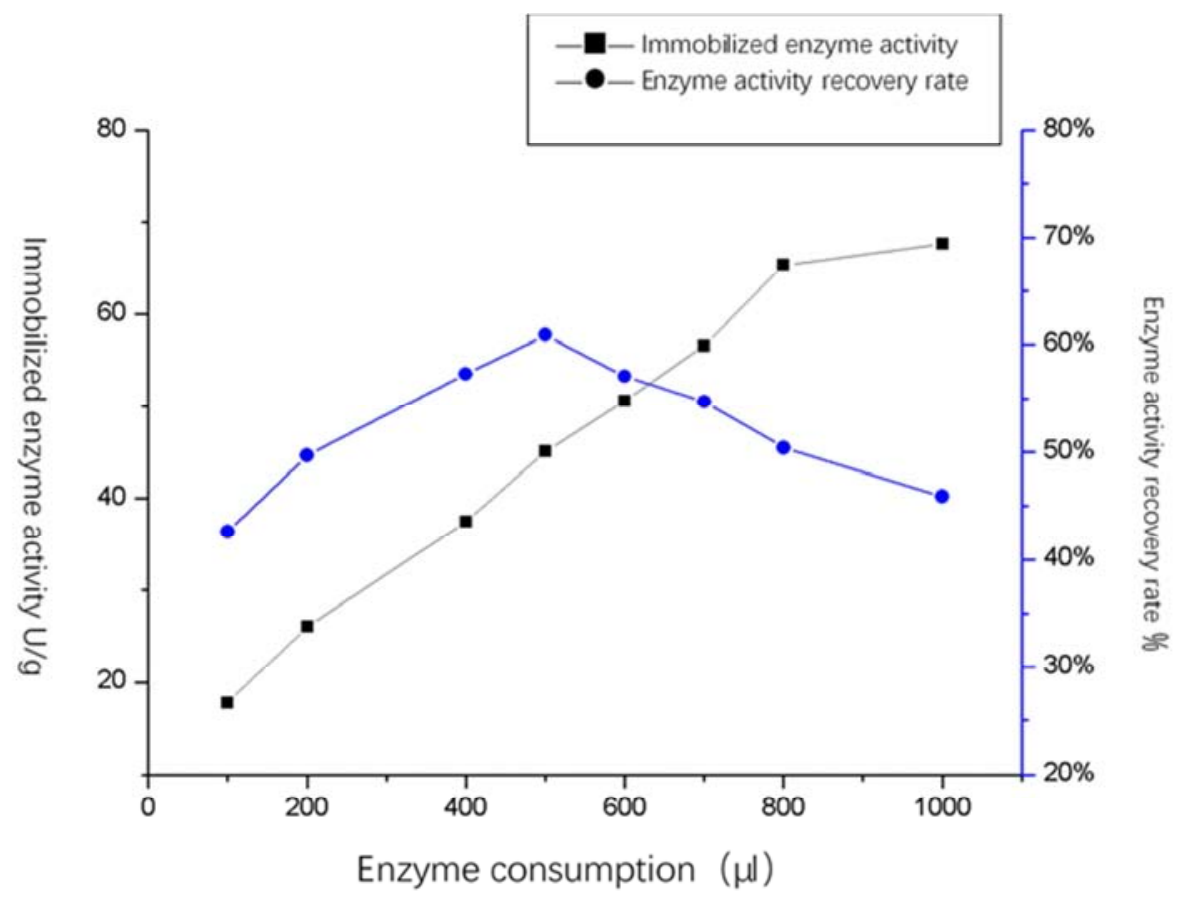

Figure 3. Effect of enzyme dosage on enzyme immobilization effect.

It can be seen from Fig. 4 that the activity of immobilized enzyme rises with the increase of crosslinking time at first. Then it decreased. It reached the maximum when the crosslinking time was $4 \mathrm{~h}$. The reason of this phenomenon is that, long crosslinking time will cause the agglomeration of nanoparticles, leading to the decline of enzyme recovery amount. Meanwhile, long crosslinking time will cause protein degeneration, reducing the activity of immobilized enzyme. [11] 


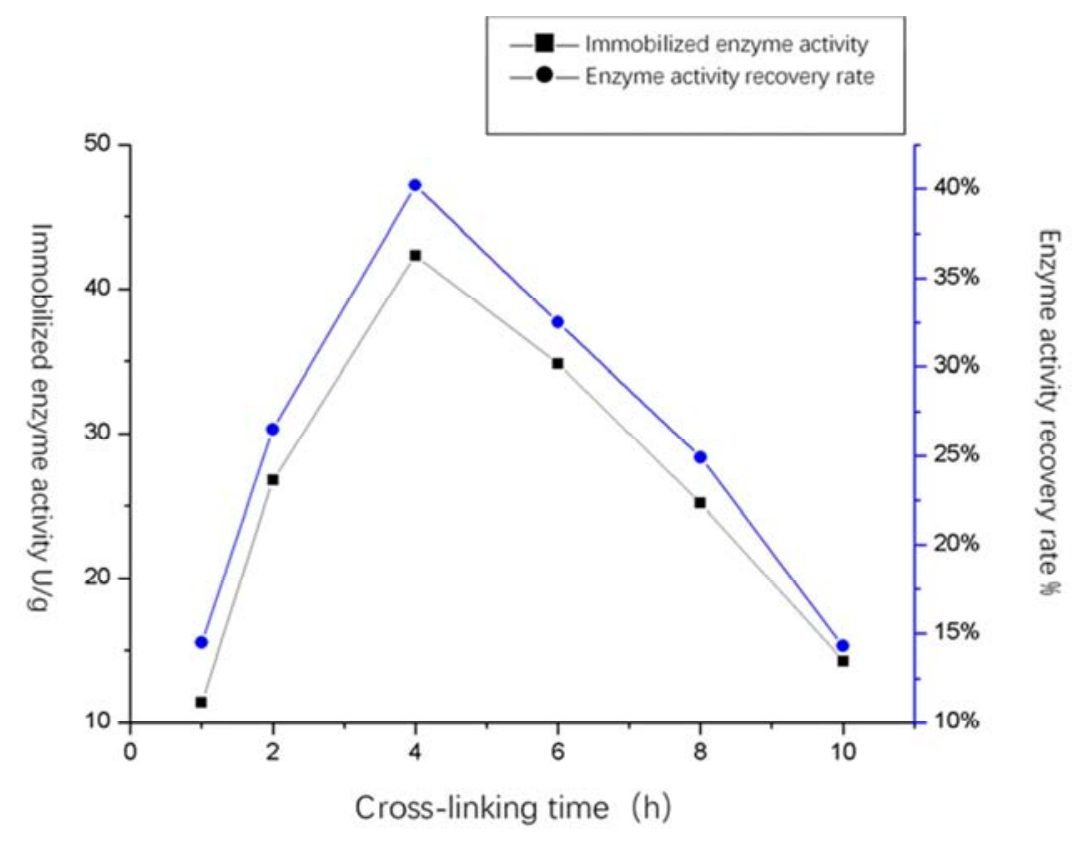

Figure 4. Effect of cross-linking time on enzyme immobilization effect.

It can be seen from Fig. 5 that, when the glutaraldehyde concentration is small, the recovery amount of enzyme will increase rapidly with the increase of glutaraldehyde concentration. But when the concentration of glutaraldehyde exceeds $2 \%$, the activity of immobilized enzyme will decrease rapidly. This is because glutaraldehyde is not only a cross-linking agent, but also a cause of enzyme denaturation. High glutaraldehyde concentration will accelerate the denaturation of enzymes, reducing the activity of immobilized enzyme.
- I- Immobilized enzyme activity

- - Enzyme activity recovery rate

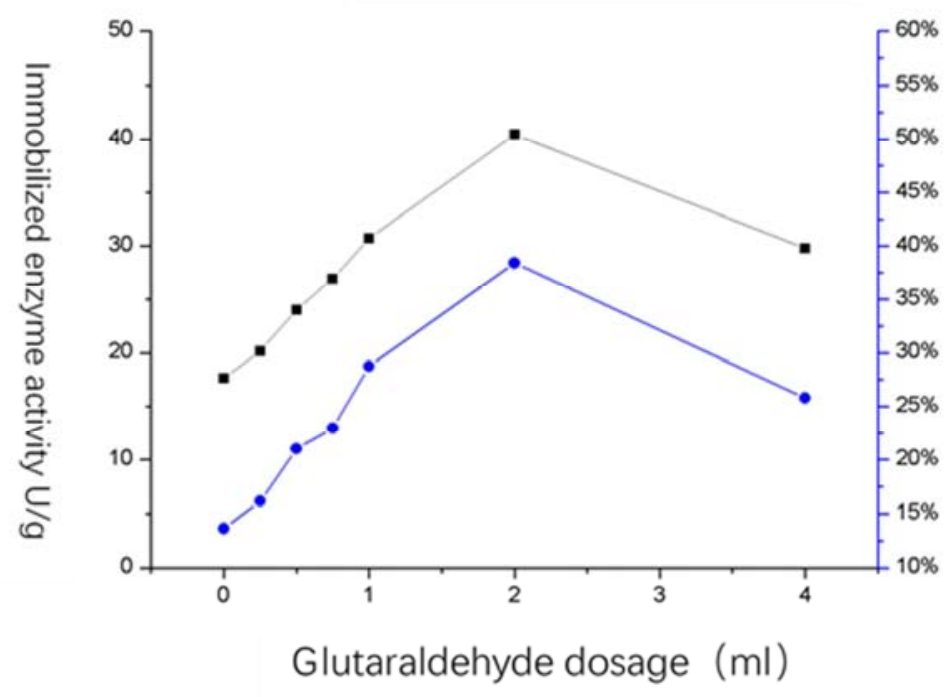

Figure 5. Effect of glutaraldehyde dosage on enzyme immobilization effect.

It can be seen from Fig. 6 that the recoveries of the immobilized enzyme reached the maximum at $1 \mathrm{~h}$, indicating that the enzyme was saturated at $1 \mathrm{~h}$. The surface area of nanoparticles is larger than any other carriers, so the absorption process can be finished in a short time. Long absorption time does no good to the effect of enzyme recovery. After $1 \mathrm{~h}$, the excess enzyme will no longer be cross-linked on the carrier. The enzyme activity will begin to decrease due to the denaturation effect. So $1 \mathrm{~h}$ is the best absorption time. [12] 


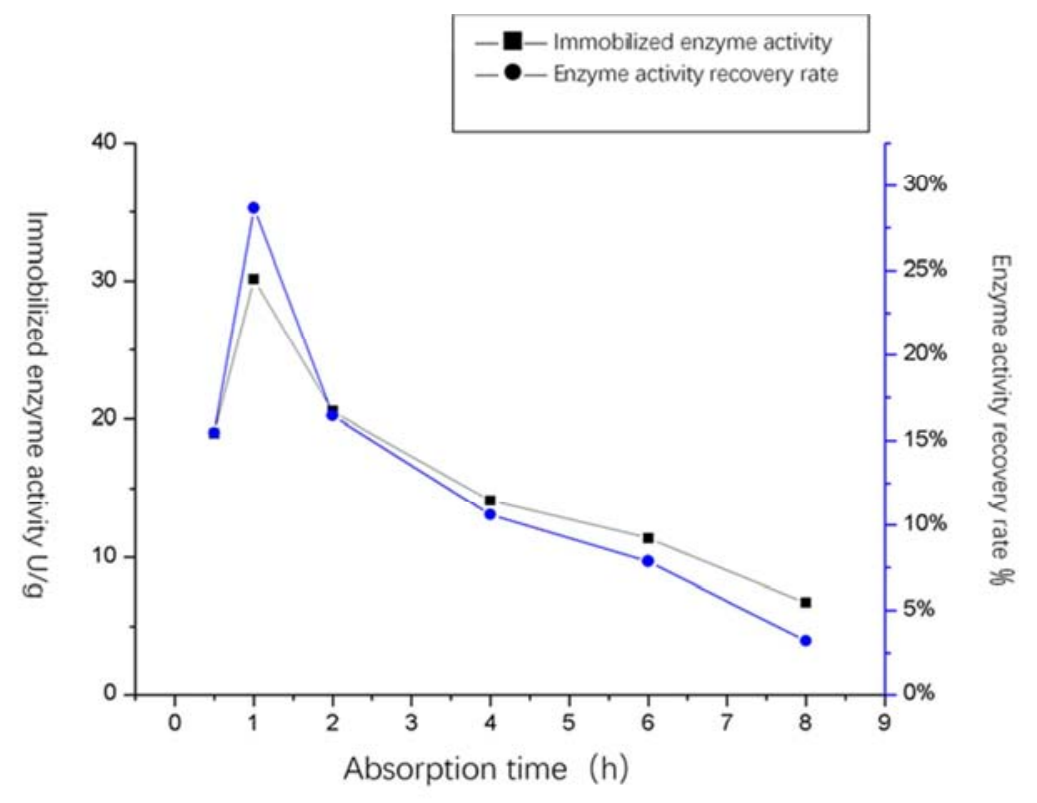

Figure 6. Effect of absorption time on enzyme immobilization effect.

It can be seen from Fig. 7 that, in the low temperature, the enzyme activity recovery effect didn't perform well. Room temperature $\left(25^{\circ} \mathrm{C}\right)$ was beneficial to the recovery of the enzyme activity of the enzyme, which reached the maximum under this condition. With the rise of temperature, the recovery rate of enzyme activity decreased. The cross-linking effect of glutaraldehyde enhanced with temperature, so the activity of immobilized enzyme rise. But if the temperature is too high, the denaturation effect of glutaraldehyde will be enhanced, resulting in the decline of immobilized enzyme activity. The high temperature itself also has strong denaturation effect. Enzyme is easy to lose its activity due to the change of protein structure. Besides, room temperature is beneficial to the stability of enzyme. The repeated use under high temperature is much easier to cause the denaturation.

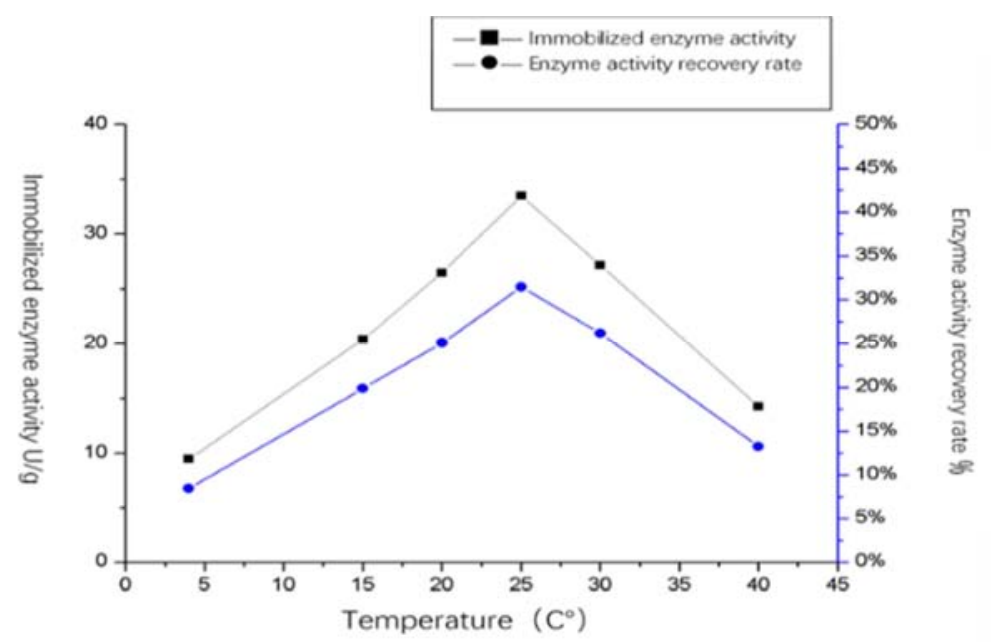

Figure 7. Effect of temperature on enzyme immobilization effect.

Orthogonal Test

The recovery rate of glutaraldehyde-modified alkaline protease is tested under different temperature, $\mathrm{pH}$, crosslinking time, adsorption time, enzyme dosage and glutaraldehyde concentration. To further investigate the complex impact on recovery rate between these factors, a four factor three level L9 orthogonal test is designed. The selected factors and their level is shown in Table 4. [13]
A: Temperature B: $\mathrm{pH}$

C: Enzyme Dosage D: Glutaraldehyde Con. centration

Table 4. The levels and factors of orthogonal test.

\begin{tabular}{lllll}
\hline \multirow{2}{*}{ Level } & Factors & & & \\
\cline { 2 - 5 } & $\mathbf{A}\left({ }^{\circ} \mathbf{C}\right)$ & $\mathbf{B}$ & $\mathbf{C}(\boldsymbol{\mu l})$ & $\mathbf{D}(\mathbf{\%})$ \\
\hline 1 & 20 & 7.0 & 400 & 0.8 \\
2 & 25 & 7.5 & 500 & 1.0 \\
3 & 30 & 8.0 & 600 & 2.0 \\
\hline
\end{tabular}


The average effect of each factor: $\mathrm{k}$ value, is calculated. $\mathrm{k}$ will reach maximum at the optimal level. It is found that the $\mathrm{pH}$ value has the greatest effect on the immobilization rate, followed by the amount of enzyme. The effect of glutaraldehyde concentration and temperature is a little bit smaller. It can be concluded that the effect of four factors on the recovery rate of enzyme activity: $\mathrm{pH}>$ enzyme dosage $>$ glutaraldehyde concentration $>$ temperature. [14]

Table 5. Table of BSA orthogonal test.

\begin{tabular}{llllll}
\hline No. & $\mathbf{A}\left({ }^{\circ} \mathbf{C}\right)$ & $\mathbf{B}$ & $\mathbf{C}(\boldsymbol{\mu l})$ & $\mathbf{D}(\%)$ & Activity $(\mathbf{U} / \mathbf{g})$ \\
\hline 1 & 20 & 7.0 & 400 & 0.8 & 30.41 \\
2 & 20 & 7.5 & 500 & 1.0 & 52.93 \\
3 & 20 & 8.0 & 600 & 2.0 & 70.71 \\
4 & 25 & 7.0 & 500 & 2.0 & 49.21 \\
5 & 25 & 7.5 & 600 & 0.8 & 61.19 \\
6 & 25 & 8.0 & 400 & 1.0 & 65.28 \\
7 & 30 & 7.0 & 600 & 1.0 & 48.14 \\
8 & 30 & 7.5 & 400 & 2.0 & 50.76 \\
9 & 30 & 8.0 & 500 & 0.8 & 66.47 \\
K1 & 54.81 & 43.71 & 53.15 & 56.04 & \\
K2 & 61.45 & 56.94 & 58.74 & 60.42 & \\
K3 & 57.16 & 71.35 & 62.38 & 58.02 & \\
R & 4.28 & 28.53 & 12.84 & 6.92 & \\
Optimal Level & A2 & B3 & C3 & D3 & \\
\hline
\end{tabular}

So, the conclusion can be drawn that when the temperature is $25^{\circ} \mathrm{C}$, the amount of enzyme is $500 \mu \mathrm{l}$, the glutaraldehyde concentration is $1 \%$, the crosslinking time is $4 \mathrm{~h}$, the adsorption time is $1 \mathrm{~h}$, and $\mathrm{pH}$ is 8 , the effect of enzyme immobilization reaches the maximum. [15]

Hydrolysis Result

The sludge is hydrolyzed by immobilized enzyme under the best reaction situation. The test result is as follows:

Table 6. Table of hydrolysis result.

\begin{tabular}{ll}
\hline Detection indicator & Rate of change \\
\hline COD & Decreasing $28.4 \%$ \\
VSS & Decreasing $34.6 \%$ \\
NH4+-N & Increasing $51.4 \%$ \\
Polysaccharide & Increasing 49.6 \\
\hline
\end{tabular}

Here is the reason for the result: Sludge floc is fractured due to the effect of immobilized enzyme. A large amount of colloidal and soluble organic matter is released to solution, while the degradation-resistant granular organics is hydrolyzed into soluble organics. And Carbohydrates are converted into polysaccharides or reducing sugars. Macromolecules are hydrolyzed into polypeptides, dipeptides and amino acids, and then further decomposed into small molecules of organic acids by deamination, ammonia and carbon dioxide. That makes the decline of COD and VSS, and the rise of $\mathrm{NH}_{4}{ }^{+}-\mathrm{N}$ and Polysaccharide. [16]

\section{Conclusion}

This article introduces the preparation method of cellulose-based nano immobilized enzyme and how to determine its performance.

According to the above research, when the temperature is $25^{\circ} \mathrm{C}$, the amount of enzyme is $500 \mu \mathrm{l}$, the glutaraldehyde concentration is $1 \%$, the crosslinking time is $4 \mathrm{~h}$ and the adsorption time is $1 \mathrm{~h}$, the effect of enzyme immobilization reaches the maximum. The prepared immobilized enzyme can effectively hydrolyze sludge, reducing the contamination in it.

Besides water treatment, immobilized enzyme also shows potential in other fields like Food, medicine, cosmetics and some other industries due to its recycling convenience and stability. [17]

\section{Acknowledgements}

My deepest gratitude goes first and foremost to Professor $\mathrm{Li}$, for his constant encouragement and guidance. Without him, this thesis could not have reached its present form.

Second, I would like to express my heartfelt gratitude to my beloved family for their loving considerations and great confidence in me all through these years.

I also owe my sincere gratitude to my friends and my fellow classmates who gave me their help and time.

At last, I want to thank the support of National Natural Science Foundation U1660107. Without their help, I cannot have the finance and equipment to finish my project.

\section{References}

[1] Akhond, M., et al., Efficient Immobilization of Porcine Pancreatic alpha-Amylase on Amino-Functionalized Magnetite Nanoparticles: Characterization and Stability Evaluation of the Immobilized Enzyme. Appl Biochem Biotechnol, 2016. 180(5): p. $954-968$.

[2] Amirbandeh, M. and A. Taheri-Kafrani, Immobilization of glucoamylase on triazine-functionalized $\mathrm{Fe} 3 \mathrm{O}$ /graphene oxide nanocomposite: Improved stability and reusability. Int J Biol Macromol, 2016. 93(Pt A): p. 1183-1191.

[3] Dutta, N., S. Biswas, and M. K. Saha, Nano-magnesium aided activity enhancement and biophysical characterization of a psychrophilic alpha-amylase immobilized on graphene oxide nanosupport. J Biosci Bioeng, 2017.

[4] He, L., et al., Functional expression of a novel alpha-amylase from Antarctic psychrotolerant fungus for baking industry and its magnetic immobilization. BMC Biotechnol, 2017. 17(1): p. 22.

[5] Hou, C., et al., Construction of enzyme immobilization system through metal-polyphenol assisted $\mathrm{Fe}_{3} \mathrm{O}_{4}$ /chitosan hybrid microcapsules. Chemical Engineering Journal, 2016. 283: p. 397-403.

[6] Wu, Z.-C., et al., Removal of $\mathrm{Cu}(\mathrm{II})$ ions from aqueous water by l-arginine modifying magnetic chitosan. Colloids and Surfaces A: Physicochemical and Engineering Aspects, 2016. 499: p. 141-149.

[7] Hu, T.-G., et al., Immobilization of Alkaline Protease on Amino-Functionalized Magnetic Nanoparticles and Its Efficient Use for Preparation of Oat Polypeptides. Industrial \& Engineering Chemistry Research, 2015. 54(17): p. 4689-4698. 
[8] Ibrahim, A., et al., Detergent and solvent compatible alkaline protease nanobiocatalyst immobilized onto functionalized rattle type magnetic core mesoporous shell silica. New Biotechnology, 2016. 33: p. S105.

[9] Ibrahim, A. S., et al., Enhancement of Alkaline Protease Activity and Stability via Covalent Immobilization onto Hollow Core-Mesoporous Shell Silica Nanospheres. Int J Mol Sci, 2016. 17(2).

[10] Junoi, S., Y. Chisti, and N. Hansupalak, Optimal conditions for deproteinizing natural rubber using immobilized alkaline protease. Journal of Chemical Technology \& Biotechnology, 2015. 90(1): p. 185-193.

[11] Li, G.-y., et al., Preparation and properties of magnetic $\mathrm{Fe}_{3} \mathrm{O}_{4-}$ chitosan nanoparticles. Journal of Alloys and Compounds, 2008. 466(1-2): p. 451-456.

[12] Pylypchuk Ie, V., et al., Gd-DTPA Adsorption on Chitosan/Magnetite Nanocomposites. Nanoscale Res Lett, 2016. 11(1): p. 168.

[13] Ling, X. M., et al., Covalent Immobilization of Penicillin G
Acylase onto $\mathrm{Fe}_{3} \mathrm{O}_{4}$ Chitosan Magnetic Nanoparticles. J Microbiol Biotechnol, 2016. 26(5): p. 829-36.

[14] Naghipour, A. and A. Fakhri, Efficient oxidation of sulfides into sulfoxides catalyzed by a chitosan-Schiff base complex of $\mathrm{Cu}(\mathrm{II})$ supported on supramagnetic $\mathrm{Fe}_{3} \mathrm{O}_{4}$ nanoparticles. Environmental Chemistry Letters, 2015. 14(2): p. 207-213.

[15] Prasertkittikul, S., Y. Chisti, and N. Hansupalak, Deproteinization of Natural Rubber Using Protease Immobilized on Epichlorohydrin Cross-linked Chitosan Beads. Industrial \& Engineering Chemistry Research, 2013. 52(33): p. 11723-11731.

[16] Sahin, S., I. Ozmen, and E. Kir, Purification, immobilization, and characterization of protease from localBacillus subtilis M-11. Asia-Pacific Journal of Chemical Engineering, 2015. 10(2): p. 241-247.

[17] Wang, S.-n., et al., Immobilized alcalase alkaline protease on the magnetic chitosan nanoparticles used for soy protein isolate hydrolysis. European Food Research and Technology, 2014. 239(6): p. 1051-1059. 